\title{
Praktik Kecurangan Akuntansi Dan Etika Profesi Akuntan
}

\author{
Mursalin \\ Fakultas Ekonomi, Universitas PGRI Palembang \\ email : mursalin@univpgri-palembang.ac.id
}

\begin{abstract}
Abstrak
Beberapa tahun terakhir ini oknum akuntan telah melanggar prinsip dasar etika profesi. Permasalahan utamanya adalah mengapa praktik kecurangan akuntansi tersebut sering berulang, apakah ada indikasi tindakan kecurangan yang terjadi adalah tindakan yang terencana atau kah memang akuntan terpaksa melakukannya. Siapa saja yang berpotensi melakukan kecurangan akuntansi di perusahaan dan etika apa saja yang dilanggar oleh akuntan tersebut. Etika profesi tidak akan dilanggar jika ada aturan dan sangsi yang jelas. Kalau semua kecurangan dibiarkan, lama kelamaan akan menjadi kebiasaan atau budaya. Oleh karena itu bila ada yang melakukan kecurangan akuntansi, harus diberikan sangsi kepada pelakunya, agar tidak menurun kepada akuntan lainnya.
\end{abstract}

Kata kunci: kecurangan akuntansi, etika profesi akuntan

\section{Pendahuluan}

Belakangan ini etika profesi akuntan menjadi diskusi berkepanjangan di tengah-tengah masyarakat bisnis. Menyadari hal demikian, etika menjadi kebutuhan penting bagi semua profesi. $\mathrm{Di}$ Indonesia, pendidikan selama ini terlalu menekankan arti penting nilai akademik dan kecerdasan otak saja. Pengajaran integritas, kejujuran, komitmen, dan keadillan seringkali diabaikan, sehingga terjadilah krisis multi dimensi seperti krisis ekonomi, krisis moral, dan krisis kepercayaan.

Akhir-akhir ini, akuntan sering dituduh sebagai penyebab krisis ekonomi. Lebih lanjut dikatakan bahwa akuntan dianggap telah bertindak menyimpang dari peraturan yang ada dan tidak berperilaku etis. Melanggar kepatutan. Hal ini disebabkan karena semakin meningkatnya persaingan membuat akuntan bertindak menyimpang dari peraturan, undangundang, dan standar pemeriksaan. Tetapi, dilema etika tidak dapat sepihak ditujukan terhadap pribadi akuntan saja, melainkan yang perlu dipertanyakan apakah akuntan mampu menerapkan standar profesi yang berkualitas tinggi dimana sejumlah faktor-faktor akan tergantung pada standar tersebut seperti pendidikan, kesadaran akan perubahan, dan lainlain. Jika kepercayaan terhadap profesi mengalami tekanan, maka pengaruh signifikan dari keterlibatan etika budaya dalam perusahaan sangan diperlukan.

Masalah etika profesi merupakan suatu isu yang sangat menarik. Tanpa etika, profesi akuntan tidak ada karena fungsi akuntansi adalah penyedia informasi untuk proses pembuatan keputusan bisnis oleh para pelaku bisnis. Para pelaku bisnis diharapkan mempunyai integritas dan kompetensi yang tinggi. Berbagai pelanggaran etika telah banyak terjadi saat ini dan dilakukan oleh akuntan, misalnya berupa perekayasaan data akuntansi untuk menunjukkan kinerja keuangan perusahaan agar terlihat lebih baik, ini merupakan pelanggaran terhadap etika profesi khususnya kode etik akuntan. Akuntan telah memiliki seperangkat kode etik yang disebut 
sebagai aturan tingkah laku moral bagi akuntan dalam masyarakat bisnis.

\section{Pembahasan}

\section{Praktik Kecurangan Akuntansi}

Praktik kecurangan akuntansi bisa timbul dalam berbagai bentuk, Simanjuntak (2008) mengklasifikasikan kecurangan (fraud) menjadi empat golongan berdasarkan pencatatan, frekuensi, konspirasi, dan keunikan.

1. Berdasarkan pencatatan

Kecurangan berupa pencatatan aset dapat dikelompokkan ke dalam tiga kategori, yaitu:

a. Pencurian aset yang tampak secara terbuka di buku, seperti duplikasi pembayaran yang tercantum pada catatan akuntansi (fraud open on the books), kecurangan jenis ini lebih mudah untuk ditemukan.

b. Pencurian aset yang tampak pada buku, namun tersembunyi di antara catatan akuntansi yang valid, seperti kickback (fraud hidden on the-books).

c. Pencurian aset yang tidak tampak pada buku dan tidak dapat diteksi melalui pengujian transaksi akuntansi "yang dibukukan", seperti: pencurian uang pembayaran piutang dagang yang telah dihapusbukukan/di-write-off (fraud off-the books), kecurangan jenis ini paling sulit ditemukan.

2. Berdasarkan frekuensi

Pengklasifikasian kecurangan berdasarkan frekuensi terjadinya yaitu:

a. Tidak berulang (nonrepeating fraud)

Kecurangan yang tidak berulang, walaupun terjadi beberapa kali, pada dasarnya bersifat tunggal. Misalnya

kecurangan dalam

pembayaran cek mingguan

karyawan, maka pelaku memerlukan kartu kerja mingguan untuk melakukan pembayaran cek yang tidak benar.

b. Berulang (repeating fraud)

Kecurangan berulang, tindakan yang menyimpang terjadi beberapa kali dan hanya dinisiasi/diawali sekali saja, selanjutnya kecurangan terjadi terus-menerus sampai dihentikan. Misalnya cek pembayaran gaji bulanan yang dihasilkan secara otomatis tanpa harus melakukan penginputan setiap saat. Penerbitan cek terus berlangsung sampai diberikan perintah untuk menghentikannya.

3. Berdasarkan konspirasi

Kecurangan yang terjadi karena adanya konspirasi bone fide maupun pseudo. Bona fide conspiracy, yaitu semua pihak sadar akan adanya kecurangan, sedangkan pseudo conspiracy, ada pihak-pihak yang tidak mengetahui terjadinya kecurangan.

4. Berdasarkan keunikan

Kecurangan berdasarkan keunikannya dapat dikelompokkan sebagai berikut:

a. Kecurangan khusus (specialized fraud)

Terjadi secara unik pada orang-orang yang bekerja pada operasi bisnis tertentu, contoh: (1) pengambilan aset yang disimpan deposan pada lembaga-lembaga keuangan, seperti bank, dana pensiun, dan reksa dana. Kecurangan jenis ini disebut juga dengan 
custodial fraud. (2) klaim asuransi yang tidak benar.

b. Kecurangan umum (garden varieties of fraud)

Dihadapi oleh semua orang dalam operasi bisnis secara umum. Misalnya kickback yaitu penetapan harga yang tidak benar, pesanan pembelian/kontrak yang lebih tinggi dari kebutuhan yang sebenarnya, pembuatan kontrak ulang atas pekerjaan yang telah selesai, pembayaran ganda, dan pengiriman barang yang tidak benar.

The Association of Certified Fraud Examiners (ACFE), Asosiasi Pemeriksa Kecurangan Bersertifikat yang berada di Amerika Serikat, menggolongkan kecurangan dalam tiga jenis atau tipologi berdasarkan perbuatan yaitu:

1. Penyimpangan atas aset (asset misappropriation)

Penyalahgunaan/pencurian aset perusahaan atau pihak lain. Ini merupakan bentuk kecurangan yang paling mudah dideteksi karena sifatnya yang tangible atau dapat diukur atau dihitung (defined value).

2. Pernyataan palsu atau salah pernyataan (fraudelent statement)

Tindakan yang dilakukan oleh pejabat atau eksekutif suatu perusahaan atau instansi pemerintah untuk menutupi kondisi keuangan yang sebenarnya dengan melakukan rekayasa keuangan (financial engineering) dalam penyajian laporan keuangannya untuk memperoleh keuntungan atau mungkin dapat dianalogikan dengan istilah window dressing.

3. Korupsi (corruption)
Jenis kecurangan ini yang paling sulit dideteksi karena menyangkut kerja sama dengan pihak lain seperti suap dan korupsi. Kecurangan ini yang terbanyak terjadi di negaranegara berkembang yang penegakan hukumnya lemah dan masih kurang kurang kesadaran akan tata kelola yang baik sehingga faktor integritas masih dipertanyakan. Korupsi sering kali tidak dapat dideteksi karena para pihak yang bekerja sama menikmati keuntungan. Termasuk didalamnya adalah penyalahgunaan

wewenang/konflik kepentingan (conflict of interest), penyuapan (bribery), penerimaan yang tidak syah/ilegal (ilegal gratuities), dan pemerasan secara ekonomi (economic extortion).

\section{Kejadian yang Terus Berulang atas Praktik Kecurangan}

Beberapa faktor menjadi pendorong mengapa kecurangan akuntansi terus berulang diuraikan berikut. Simanjuntak (2008) menyoroti faktor yang mendorong seseorang melakukan kecurangan bisa berasal dari faktor generik dan individu yaitu:

1. Faktor generik/umum

Merupakan faktor yang berhubungan dengan organisasi sebagai korban perbuatan kecurangan. Faktor ini meliputi:

a. Kesempatan (opportunity)

Kesempatan

untuk melakukan kecurangan tergantung pada kedudukan pelaku terhadap objek kekurangan. Umumnya, manajemen suatu organisasi atau perusahaan memiliki potensi yang lebih besar untuk melakukan kecurangan daripada karyawan. Tetapi 
patut digaris bawahi bahwa kesempatan untuk melakukan kecurangan selalu ada pada setiap kedudukan.

b. Pengungkapan (exposure)

Terungakapnya suatu kecurangan dalam organisasi atau perusahaan belum menjamin tidak terulangnya kecurangan tersebut baik oleh pelakau yang sama maupun oleh pelaku yang lain. Oleh karena itu, setiap pelaku kecurangan seharusnya dikenakan sanksi apabila perbuatannya terungkap.

\section{Faktor Individu}

Faktor yang berhubungan dengan individu sebagai pelaku kecurangan. Faktor ini terdiri dari:

a. Ketamakan (greed)

Ketamakan berhubungan dengan moral individu. Pandangan hidup dan lingkungan berperan dalam pembentukan moral seseorang.

b. Kebutuhan (need)

Berhubungan dengan pandangan/pikiran dan keperluan pegawai/pejabat yang terkait dengan aset yang dimiliki perusahaan/instansi/organisa si tempat ia bekerja. Selain itu tekanan (pressure) yang dihadapi dalam bekerja dapat menyebabkan orang yang jujur mempunyai motif untuk melakukan kecurangan.

Amrizal (2004) menggaris bawahi bahwa pada dasarnya praktik kecurangan akuntansi akan terus berulang dalam suatu entitas jika:

1. Pengendalian intern tidak ada atau lemah atau dilakukan dengan longgar dan tidak efektif.
2. Pegawai dipekerjakan tanpa memikirkan kejujuran dan integritas mereka.

3. Pegawai diatur, diekspolitasi denga tidak baik, disalahgunakan atau ditempatkan dengan tekanan yang besar untuk mencapai sasaran dan tujuan keuangan yang mengarah tindakan kecurangan.

4. Model manajemen sendiri melakukan kecurangan, tidak efisien dan atau tidak efektif serta tidak taat terhadap hukum dan peraturan yang berlaku.

5. Pegawai yang dipercaya memiliki masalah pribadi yang tidak dapat dipecahkan, biasanya masalah keuangan, kebutuhan kesehatan keluarga, dan gaya hidup yang berlebihan.

6. Industri dimana perusahaan menjadi bagiannya, memiliki sejarah atau tradisi kecurangan.

\section{Praktik Kecurangan antara Motif Terencana dan Keterpaksaan}

Faktor pendorong yang telah dijelaskan pada pembahasan sebelumnya menjadi dasar mengapa seseorang melakukan kecurangan. Faktor pendorong itu pulalah yang menyebabkan seseorang dapat melakukan perencanaan untuk melakukan kecurangan. Seperti yang terjadi pada kasus Enron Corp., imingiming insentif moneter yang cukup besar, memicu pada eksekutifnya untuk melakukan manajemen laba untuk meraih insentif yang besar. Kesempatan yang ada dan rendahnya pengendalian internal serta tidak independennya akuntan dari Arthur Anderson menyebabkan kecurangan itu mudah itu terjadi.

Kecurangan akuntansi bisa juga terjadi bila ada suatu keterpaksaan, misalnya ketergantungan terhadap klien. Misalnya proporsi total 
pendapatan Kantor Akuntan Publik (KAP) milik auditor itu sebagian besar berasal dari satu perusahaan atau kelompok perusahaan (Sabeni, 2006). Atau bisa disebabkan karena tekanantekanan dari pihak manajemen yang menyebabkan akuntan tidak bisa berkutik. Pada saat hal tersebut terjadi, maka independensi dari para akuntan akan benar-benar diuji.

Banyak kasus kecurangan, khususnya kasus pencurian dan penggelapan aset, biasanya terdapat tiga faktor yang mendasari yaitu ada satu tekanan pada seseorang, seperti kebutuhan keuangan, adanya kesempatan untuk melakukan kecurangan dan menyembunyikan kecurangan yang dilakukan, adanya cara pembenaran prilaku tersebut yang sesuai dengan tingkatan integritas pelakunya (Amrizal, 2004).

\section{Pelaku Kecurangan Akuntansi}

Pelaku kecurangan akuntansi bisa berasal dari internal maupun eksternal perusahaan.

1. Internal Perusahaan

a. Karyawan

Karyawan melakukan

kecurangan bertujuan untuk keuntungan individu, misalnya salah saji yang berupa penyalahgunaan aset.

b. Manajemen

Pihak manajemen melakukan kecurangan biasanya untuk kepentingan perusahaan, yaitu salah saji yang timbul karena kecurangan pelapor keuangan. Namun tidak menutup kemungkinan, manajemen melakukan kecurangan hanya untuk kepentingan pribadi. Seperti pada kasus Enron, para eksekutifnya memberikan laporan keuangan yang salah dengan melebih-lebihkan labanya guna meraih kompensasi moneter yang berasal dari perusahaan.

2. Eksternal perusahaan

Pihak eksternal yang berpotensi melakukan kecurangan juka tidak memegang teguh kode etik profesi antara lain auditor, akuntan publik. Konflik kepentingan selalu ada, misalnya tidak independennya auditor maupun akuntan pada kasus Enron. Pihak lain yang berpotensi terjadi kecurangan bisa berasal dari pelanggan, distributor supplier perusahaan.

\section{Cara Mendeteksi dan Mencegah Praktik Kecurangan \\ Mendeteksi Praktik Kecurangan}

Pendeteksian terjadi praktik kecurangan bisa dlakukan dengan mengenali gejala-gejala antara lain:

1. Gejala kecurangan pada manajemen

Umumnya agak sulit dideteksi, namun gejala dapat dikenali yaitu timbulnya ketidakcocokan diantara manajemen puncak, rendahnya moral, dan motivasi karyawan, Departemen akuntansi kekurangan staf, tingkat komplain yang tinggi terhadap organisasi/perusahaan dari pihak konsumen, pemasok, atau badan otoritas, terjadi kekurangan kas secara tidak teratur dan tidak terantisipasi, menurunnya tingkat penjualan atau laba sementara utang dan piutang usaha meningkat, perusahaan mengambil kredit sampai batas maksimal untuk jangka waktu yang lama, terdapat kelebihan persediaan yang signifikan, terdapat peningkatan jumlah ayat jurnal penyesuaian pada akhir tahun buku. 
2. Gejala kecurangan pada karyawan/pegawai

Gejala kecurangan yang dilakukan oleh karyawan atau pegawai dapat dikenali antara lain yaitu pembuatan ayat jurnal penyesuaian tanpa otoritas manajemen dan tanpa perincian/penjelasan pendukung, melakukan pengeluaran tanpa dokumen pendukung, pencatatan yang salah/tidak akurat pada buku jurnal/besar, penghancuran, penghilangan, pengrusakan dokumen pendukung pembayaran, kekurangan barang yang diterima, kemahalan harga barang yang dibeli, munculnya faktur ganda, penggantian mutu barang (Sie Infokum, 2008).

Perubahan prilaku drastis dari individu yang melakukan kecurangan bisa digunakan sebagai indikasi (Sie Infokum, 2008), antara lain yaitu:

1. Perubahan prilaku secara signifikan, seperti: easy going, tidak seperti biasanya, gaya hidup mewah, mobil atau pakaian mahal.

2. Gaya hidup di atas rata-rata.

3. Sedang mengalami trauma emosional di rumah atau tempat kerja.

4. Penjudi berat.

5. Peminum berat.

6. Sedang dililit hutang.

7. Temuan audit atas kekeliruan (error) atau ketidakberesan (irregularities) dianggap tidak material ketika ditemukan.

8. Bekerja tenang, bekerja keras, bekerja melampaui jam kerja, sering bekerja sendiri.

Amrizal (2004) menguraikan garis besar cara mendeteksi kecurangan menurut ACFE adalah sebagai berikut:
1. Kecurangan laporan keuangan (financial statement fraude) Kecurangan dalam penyajian laporan keuangan umumnya dapat dideteksi melalui analisis laporan keuangan sebagai berikut:

a. Analisis vertikal, yaitu teknik yang digunakan untuk menganalisis hubungan antara item-item dalam laporan laba rugi, neraca, atau laporan arus kas dengan menggambarkannya dalam persentase.

b. Analisis horizontal, yaitu teknik untuk menganalisis persentase-persentase

perubahan item laporan keuangan selama beberapa periode laporan.

c. Analisis rasio, yaitu alat untuk mengukur hubungan antara nilai-nilai item dalam laporan keuangan sebagai contoh adalah current ratio, adanya penggelapan uang atau pencurian kas dapat menyebabkan turunnya perhitungan rasio tersebut.

2. Penyalahgunaan aset (asset misappropriation)

Variasi pendeteksian kecurangan jenis ini sangat beragam. Pemahaman terhadap pengendalian intern atas pos-pos tersebut akan sangat membantu dalam mendeteksi kecurangan. Metode-metode yang bisa digunakan antara lain:

a. Analiytical review

Review atas berbagai akun yang mungkin menunjukan ketidak biasaan atau kegiatan-kegiatan yang tidak diharapkan.

b. Stastitical sampling

Melakukan sampling atas pos-pos tertentu yang 
dicurigai, misalnya persediaan. Dokumen dasar pembelian dapat diuji secara sampling untuk menentukan ketidakbiasaan (irregularities), metode deteksi ini akan efektif jika ada kecurigaan terhadap atau attributnya, misalnya pemasok fiktif. Suatu daftar alamat PO BOX akan mengungkapkan adanya pemasok fiktif.

c. Vendor or outsider complaints

Komplain/keluhan dari konsumen, pemasok, atau pihak lain merupakan alat deteksi yang baik yang dapat mengarahkan auditor untuk melakukan pemeriksaan lebih lanjut.

d. Site visite - observation

Observasi ke lokasi biasanya dapat mengungkapkan ada tidaknya pengendalian intern di lokasi-lokasi tersebut.

\section{Korupsi (corruption)}

Kecurangan ini dapat dideteksi melalui keluhan dari rekan kerja yang jujur, laporan dari rekan, atau pemasok yang tidak puas dan menyampaikan komplain ke perusahaan. Atas sangkaan terjadinya kecurangan ini kemudian dilakukan analisis terhadap tersangka atau transaksinya.

\section{Mencegah Praktik Kecurangan}

Pencegahan terjadinya praktik kecurangan akuntasi dapat dilakukan dengan beberapa cara. Wilopo (2006) dalam penelitiannya mengemukakan bahwa upaya menghilangkan prilaku tidak etis manajemen dan kecenderungan kecurangan akuntansi dapat dilakukan antara lain dengan:
1. Mengefektifkan pengendalian internal, termasuk penegakan hukum.

2. Perbaikan sistem pengawasan dan pengendalian.

3. Pelaksanaan good governance.

Memperbaiki moral dari pengelola perusahaan, yang diwujudkan dengan mengembangkan sikap komitmen terhadap perusahaan, negara, dan masyarakat.

\section{Etika Profesi Akuntan}

Dalam etika profesi, memiliki komitmen moral yang tinggi, yang bisanya dituangkan dalam bentuk aturan khusus yang menjadi pegangan bagi setiap orang yang mengemban profesi yang bersangkutan. Aturan ini merupakan aturan main dalam menjalankan atau mengemban pofesi tersebut yang biasanya disebut sebagai kode etik yang harus dipenuhi dan ditaati oleh setiap profesi. Menurut Chua, dkk (1994) menyatakan bahwa etika profesional juga berkaitan dengan prilaku moral yang lebih terbatas pada kekhasan pola etika yang diharapkan untuk profesi tertentu.

Setiap profesi yang memberikan pelayanan jasa pada masyarakat harus memiliki kode etik yang merupakan seperangkat prinsip-prinsip moral dan mengatur tentang prilaku profesional (Agoes, 1996). Tanpa etika, profesi akuntan tidak akan ada karena fungsi akuntansi adalah penyedia informasi untuk proses pembuatan keputusan bisnis oleh para pelaku bisnis. Para pelaku bisnis ini diharapkan memiliki integritas dan kompetensi yang tinggi (Abdullah dan Halim, 2002).

Pihak-pihak yang berkepentingan terhadap etika profesi adalah akuntan publik, penyedia informasi akuntansi dan mahasiswa akuntansi (Suhardjo dan Mardiasmo, 2002). Etika profesi merupakan karakteristik suatu profesi 
yang membedakannya denga profesi lain yang berfungsi untuk mengatur tingkah laku para anggotanya (Boynton dan Kell, 1996).

Kode etik berkaitan dengan prinsip etika tertentu yang berlaku untuk suatu profesi, terdapat empat pinsip di dalam etika profesi (Keraf, 1998) yaitu:

1. Prinsip tanggung jawab

2. Prinsip keadilan

3. Prinsip otonomi

4. Prinsip integritas moral.

\section{Faktor-faktor yang Mempengaruhi Sikap dan Perilaku Etis Akuntan Publik}

Griffin dan Ebert (1998) mendefinisikan perilaku etis sebagai perilaku yang sesuai dengan normanorma sosial yang diterima secara umum sehubungan dengan tindakantindakan yang bermanfaat dan yang membahayakan. Prilaku kepribadian merupakan karakteristik individu dalam menyesuaikan diri dengan lingkungannya, karakteristik yang dimaksud meliputi: sifat, kemampuan, nilai, keterampilan, sikap serta intelegensi yang muncul dalam pola perilaku seseorang. Jadi prilaku merupakan perwujudan atau manifestasi karakteristik seseorang dalam menyesuaikan diri dengan lingkungannya.

Dalam hubungannya dengan akuntan publik, berdasarkan Sriwahjoeni dan Gudono (2000) menyatakan bahwa ada beberapa faktor yang memungkinkan berpengaruh terhadap sikap dan perilaku etis akuntan, termasuk akuntan publik. Faktor-faktor tersebut antara lain:

1. Faktor posisi atau kedudukan

Bahwa semakin tinggi posisi atau kedudukan di KAP (dalam hal ini partner dan manajer) cenderung memiliki pemikiran etis yang rendah, sehingga berakibat pada rendahnya sikap dan perilaku etis mereka.

2. Faktor imbalan yang diterima (berupa gaji/upah dan penghargaan/insentif)

Pada dasarnya seseorang yang bekerja, mengharapkan imbalan yang sesuai dengan pekerjaannya. Karena dengan upah yang sesuai dengan pekerjaannya, maka akan timbul pula rasa gairah kerja yang semakin baik dan ada rasa kecenderungan untuk bekerja secara jujur disebabkan ada rasa timbal balik yang selaras dan tercukupi kebutuhannya. Selain gaji/upah, seseorang yang bekerja membutuhkan penghargaan atas hasil karya yang telah dilakukan, baik penghargaan yang bersifat materil maupun non materil. Jika ia mendapatkan penghargaan sesuai dengan karyanya, maka si pekerja akan berbuat sesuai aturan kerja dalam rangka menjaga citra profesinya baik di dalam maupun diluar pekerjaannya.

3. Faktor pendidikan (formal, nonformal, dan informal)

Bahwa pendidikan akuntansi (pendidikan formal) mempunyai pengaruh yang besar terhadap prilaku etis akuntan publik.

4. Faktor organisasional (perilaku atasan, lingkungan kerja, budaya organisasi hubungan dengan rekan kerja)

Komitmen atasan merupakan wibawa dan profesi, bila atasan tidak memberi contoh yang baik pada bawahan, maka akan menimbulkan sikap dan perilaku etis tidak baik dalam diri bawahan sebab ia merasa bahwa atasannya bukan pemimpin yang 
baik. Lingkungan kerja turut menjadi faktor yang mempengaruhi etika individu. Lingkungan kerja yang baik akan membawa pengaruh yang baik pula pada segala pihak, termasuk para pekerja, hasil pekerjaan dan perilaku di dalamnya.

5. Faktor lingkungan keluarga

Pada umumnya individu cenderung untuk memilih sikap yang konformis/searah dengan sikap dan perilaku orang-orang yang dianggapnya penting (dalam hal ini anggota keluarga). Kecenderungan ini antara lain di motivasi oleh keinginan untuk berafiliasi dan keinginan untuk menghindari konflik. Jadi jika lingkungan keluarga bersikap dan berperilaku etis, maka yang muncul adalah sikap dan perilaku etis pula.

6. Faktor pengalaman hidup

Beberapa pengalaman hidup yang relevan dapat mempengaruhi sikap etis apabila pengalaman hidup tersebut meninggalkan kesan yang kuat. Apabila seseorang dapat mengambil pelajaran dan pengalaman masa lalunya, maka akan menumbuhkan sikap dan perilaku yang semakin etis.

7. Faktor religiusitas

Agama sebagai suatu sistem, mempunyai pengaruh dalam pembentukan sikap karena ia meletakkan dasar konsep moral dalam individu. Setiap agama mengajarkan konsep sikap dan perilaku etis, yang menjadi stimulus dan dapat memperteguh sikap dan perilaku etis.

8. Faktor hukum (sistem hukum dan sanksi yang diberikan)

Bahwa hukum yang berlaku pada suatu profesi hendaklah mengandung muatan etika agar anggota profesi merasa terayomi. Demikian halnya dengan sanksi yang dikenakan harus tegas dan jelas sehingga anggota cenderung tidak mengulangi kesalahan yang sama dalam kesempatan yang berbeda.

9. Faktor emotional quotient (EQ)

$E Q$ adalah bagaimana seseorang itu pandai mengendalikan perasaan dan emosi pada setiap kondisi yang melingkupinya. EQ lebih penting daripada IQ. Bagaimanapun juga seseorang yang cerdas bukanlah hanya cerdas dalam hal intelektualnya saja, tetapi intelektualitas tanpa adanya EQ dapat melahirkan prilaku yang tidak etis.

Berdasarkan faktor-faktor di atas, dapat disimpulkan bahwa sikap akan menentukan warna atau corak tingkah laku seseorang untuk berprilaku etis dan tidak etis.

\section{Kode Etik sebagai Etika Profesi Akuntan}

Etika profesi akuntan di Indonesia diatur dalam Kode Etik Akuntan Indonesia. Kode etik ini mengikat para anggota Ikatan Akuntan Indonesia (IAI) dan dapat dipergunakan oleh akuntan lainnya yang bukan atau belum menjadi anggota IAI. Kode etik ialah norma prilaku yang mengatur hubungan antara akuntan dengan kilennya, antara akuntan dengan sejawat, dan antara profesi dengan masyarakat (Sriwahjoeni dan Gudono, 2000).

Di dalam kode etik terdapat muatan-muatan etika, yang pada dasarnya bertujuan untuk melindungi kepentingan anggota dan kepentingan masyarakat yang menggunakan jasa profesi. Terdapat dua sasaran pokok dari kode etik ini yaitu: (1) kode etik bermaksud melindungi masyarakat 
dari kemungkinan dirugikan oleh kelalaian baik secara sengaja ataupun tidak sengaja dari kaum profesional dan (2) kode etik juga bertujuan melindungi keluhuran profesi tersebut dari prilaku-prilaku buruk orang-orang tertentu yang mengaku dirinya profesional (Keraf, 1998).

Di Indonesia, penegakan kode etik dilaksanakan oleh beberapa organisasi, yaitu: Kantor Akuntan Publik (KAP), Kompartemen Akuntan Publik IAI, Departemen Keuangan RI, dan BPKP. Selain organisasi di atas, pengawasan terhadap kode etik juga dapat dilakukan sendiri oleh para anggota dan pimpinan KAP.

Bagi profesi auditor, Indonesia telah disuguhi konsep etika profesi yang menyentuh dari Kell, dkk (2001) dalam bukunya Modern Auditing yang telah diterbitkan berkali-kali. la menyatakan:" Ethics consists of moral principles and standard of conduct. In general use the word ethics relates to the philosophy of human conduct and principles of human morality and duty. Professional ethics include standards of behaviour for a professional person that are designed for both practical and idealistic purposes.

Betapa esensialnya kepentingan publik yang harus dilindungi oleh sifat independensi dan kejujuran seorang auditor dalam berprofesi. Namun, tidak dapat diketahui dimana fungsi dan etika pengauditan yang secara teknik dapat mendeteksi jika ada penyelewengan pada sistem pemerintahan baik untuk penyusunan anggaran maupun aktivitas keuangan lainnya. Publik seakan dikelabuhi dengan berbagai informasi dari hasil audit yang selalu wajar-wajar saja. Penyelewengan tidak menjadi halangan untuk tetap dianggap suatu kewajaran bagi auditor dengan jaminan sejumlah upeti dari pasien yang bersangkutan. Tanpa mengacu pada kode etik, maka hal tersebut bukan merupakan sebuah malpraktek bagi editor.

Pada kode etik akuntan wajib menekankan sikap independen bagi auditor publik (ekstern) yang memeriksa apakah suatu laporan keuangan badan usaha komersial disusun berdasarkan Standar Akuntansi yang berlaku di Indonesia dalam suatu audit yang bersifat umum sehingga auditor negara (staf BPK). Dalam pengauditan laporan keuangan usaha komersial auditor diharuskan bebas dari intervensi manajemen, pemilik, kreditur atas suatu entitas usaha dalam menentukan opini auditor. Dia harus mewakili kepentingan publik (pemilik saham dan lain-lain) secara seimbang dalam menilai kewajaran suatu laporan. Sikap independensi penting untuk menopang profesionalisme auditor dalam suatu penugasan khusus seperti audit investigasi kegiatan tertentu seperti dalam pengauditan dugaan korupsi. Keahlian teknis akan tak bermakna tanpa independensi dan kejujuran.

Namun demikian jika kita lebih menyelami makna frase tersebut dalam konteks kepentingan publik yang lebih luas, sikap dasar independensi dan kejujuran sebagai dua elemen yang tak terpisahkan sebagai kode etik bagi seorang auditor juga berlaku untuk auditor negara (staf BPK). Profesionalisme dari kedua sikap tersebut sampai sekarang belum dapat terpenuhi dengan adanya sikap ganda yang sensitif terhadap keberadaan rupiah atau dollar sebagai ucapan terimakasih atas proyek yang dilakukan.

\section{Upaya Penegakan Etika Profesi Akuntan}

Pelanggaran etika pofesi akuntan di perusahaan memang banyak, tetapi upaya untuk menegakan etika perlu 
digalakkan. Misalnya, perusahaan tidak perlu berbuat curang untuk meraih kemenangan. Hubungan yang tidak transparan dapat menimbulkan hubungan istimewa atau kolusi dan memberikan peluang untuk korupsi.

Dari mana upaya penegakan etika profesi akuntan dimulai? Etika profesi akuntan paling gampang diterapkan di perusahaan sendiri. Pemimpin perusahaan memulai langkah ini karena mereka menjadi panutan bagi karyawannya. Selain itu, etika bisnis harus dilaksanakan secara transparan. Pemimpin perusahaan seyogyanya bisa memisahkan kepentingan perusahan dengan milik sendiri. Dalam operasinya, perusahaan mengikuti aturan berdagang yang diatur oleh tata cara undang-undang.

Etika profesi akuntan tidak akan dilanggar jika ada aturan dan sangsi. Kalau semua tingkah laku salah dibiarkan, lama kelamaan akan menjadi kebiasaan. Repotnya, norma yang salah ini akan menjadi budaya. Oleh karena itu bila ada yang melanggar aturan diberikan sangsi untuk memberi pelajaran kepada yang bersangkutan.

Upaya yang dapat dilakukan oleh perusahaan untuk menegakkan budaya transparansi antara lain: (1) penegakan budaya berani bertanggung jawab atas segala tingkah lakunya. Individu yang mempunyai kesalahan jangan bersembunyi di balik institusi. Untuk menyatakan kebenaran kadang dianggap melawan arus, tetapi sekarang harus ada keberanian baru untuk menyatakan pendapat, (2) ukuran-ukuran yang dipakai untuk mengukur kinerja jelas. Bukan berdasarkan kedekatan dengan atasan, melainkan kinerja, (3) pengelolaan sumber daya manusia harus baik, dan (4) visi dan misi perusahaan jelas yang mencerminkan tingkah laku dan budaya organisasi.
Hal lain yang juga mempengaruhi seseorang berperilaku etis adalah lingkungan, yang salah satunya ialah lingkungan dunia pendidikan. Dunia pendidikan akuntansi juga mempunyai pengaruh yang besar terhadap perilaku etis akuntan (Sudibyo, 1995), oleh sebab itu perlu diketahui pemahaman calon akuntan (mahasiswa) terhadap masalahmasalah etika, dalam hal ini berupa etika bisnis dan etika profesi akuntan yang mungkin telah atau akan mereka hadapi nantinya. Terdapatnya mata kuliah yang berisi ajaran moral dan etika sangat relevan untuk disampaikan kepada mahasiswa dan keberadaan pendidikan etika ini juga memiliki peranan penting dalam perkembangan pofesi di bidang akuntansi di Indonesia.

\section{Kesimpulan}

Berdasarkan pembahasan di atas, maka dapat disimpulkan bahwa:

1. Praktik kecurangan akuntansi dalam organisasi/perusahaan hanya bisa dicegah apabila ada komitmen yang tinggi untuk tidak melakukan berbagai bentuk kecurangan dari masingmasing individu pelaku, manajemen maupun pihak lain yang terlibat. Mendeteksi dan pencegahan terhadap kecurangan akuntansi dapat dilakukan melalui pengendalian intern, penegakan hukum, dan melaksanakan good governance, tetapi jika moral tidak berubah dan sikap komitmen yang tinggi terhadap segala bentuk praktik kecurangan tidak terlaksana, maka semua langkah yang ditempuh tidak akan berguna.

2. Penegakan etika profesi merupakan kunci untuk 
memberikan kepercayaan kepada masyarakat terhadap jasa yang diberikan oleh akuntan publik, apabila etika profesi yang menjadi landasan bagi akuntan publik tidak dijalankan semestinya, maka akan berdampak kepada munculnya masalah berupa ketidakpercayaan masyarakat terhadap jasa profesional yang diberikan.

3. Penegakan etika akuntan publik masih terkendala dalam pelaksanaannya karena adanya kesalahan dalam sistem pendidikan, lemahnya penegakan hukum, dan adanya tumpang tindih dalam praktik penyelesaian pelanggaran, yang seharusnya tidak terjadi.

4. Semua organisasi yang mempunyai tugas melakukan penegakan etika profesi akuntan harus terus berusaha menciptakan suatu terobosan baru dalam upaya penegakan etika agar sesuai dengan tuntutan masyarakat bisnis.

\section{DAFTAR PUSTAKA}

Abdullah, Syukry dan Abdul Halim. 2002. Pengintegrasian Etika dalam Pendidikan dan Riset Akuntansi. Kompak. STIE YO. Jakarta.

Agoes, Sukrisno. 1996. Makalah: Penegakan Kode Etik Akuntan Indonesia. Konvensi Nasional Akuntansi III IAI. Semarang.

Amrizal. 2004. Pencegahan dan Pendeteksian Kecurangan oleh Internal Audit. BPKP. Jakarta.
Boynton, Wiliam C., Johnson, Raymond N., and Walter G. Kell. 2001. Modern Auditing. 7th, Edition. John Wiley \& Sons, Inc. New York.

Chua, F. C, M. H. B. Perera dan M. R. Mathews. 1994. Integration of Ethics into Tertiary Accounting Programmers in new Zealand and Australia. Dalam Accounting Education for the 21st Century: The Global Chalange, edited by Jane $\mathrm{O}$. Burns and Beivesd $\mathrm{E}$. Needles Jr. Edition 1. Sn: International Association for Accounting Education and Research.

Ebert, Ronald J. And Ricky W. Griffin. 2006. Bisnis. Alih bahasa: Rd. Soemarnegara. Erlangga. Jakarta.

Keraf, A. Sonny. 1998. Etika Bisnis, Tuntutan, dan Relevansinya. Penerbit Kanisius. Yogyakarta.

Sabeni, A. 2006. Auditor Nakal: Kesengajaan atau Keterpaksaan? Diunduh dari: www.suaramerdeka.com/harian/0 608/12/eko08.htm, tanggal 15 Januari 2017.

Sie Infokum. 2009. Kecurangan (Fraud). Apa dan Mengapa? Diunduh dari: www.jdih.bpk.go.id/informasihuku $\mathrm{m} /$ fraud (kecurangan).pdf, tanggal 15 Januari 2017.

Simanjuntak, R. 2008. Kecurangan: Pengertian dan Pencegahan. Diunduh dari: www.asei.co.id/internal/docs/asei kecurangan.docs, tanggal 15 Januari 2017. 
Sriwahjoeni dan M. Gudono. 2000. Persepsi Akuntan Terhadap Kode Etik Akuntan. Jurnal Riset Akuntansi Indonesia (JRAI) No. 2 Vol. III Edisi Juli. Ikatan Akuntan Indonesia (IAI). Jakarta.

Sudibyo, Bambang. 1995. Kemiskinan dan Kesenjangan di Indonesia. Bagian Penerbitan Aditya Media. Yogyakarta.

Suhardjo, Y dan Mardiasmo. 2002. Persepsi Akuntan Publik, Pemakai Informasi Akuntansi dan
Mahasiswa Akuntansi Terhadap Edvertensi Kantor Akuntan Publik Eks Keresidenan Semarang. Kompak. STIE YO. Jakarta.

Wilopo. 2006. Makalah: Analisis Faktor-faktor yang Berpengaruh Terhadap Kecenderungan Kecurangan Akuntansi: Studi pada Perusahaan Publik dan Badan Usaha Milik Negara di Indonesia. Simposium Nasional Akuntansi (SNA) Ke-9, 23-26 Agustus $2006 . \quad$ Padang. 